\title{
Growth, Yield and Seed Quality of Sunnhemp (Crotalaria juncea L.) as Influenced by Foliar Nutrition and Pinching
}

\author{
S. Mandal, A. Dutta and P. K. Bhattacharyya*
}

Bidhan Chandra Krishi Viswavidyalaya, Mohanpur, West Bengal (741 252), India

\section{Corresponding Author}

P. K. Bhattacharyya

e-mail: bhattacharyya.pk@gmail.com

\author{
Article History \\ Article ID: AR1848a \\ Received in $29^{\text {th }}$ September, 2017 \\ Received in revised form $5^{\text {th }}$ October, 2017 \\ Accepted in final form $7^{\text {th }}$ October, 2017
}

\begin{abstract}
Field experiment was conducted during rainy (Kharif) season of 2015 and 2016 to study the effects of pinching of terminal bud and foliar nutrition at flowering stage on Growth, yield and seed quality of Sunnhemp (Crotalaria juncea L.). Pinching of terminal bud when the plant attains a height of $90 \mathrm{~cm}$ in main plots and foliar nutrition at flowering stage in sub plots were studied in split plot design with four replications. The individual plant performance for growth parameters, seed yield and yield contributing parameters as well as total seed yield revealed that pinching of sunnhemp at a height of $90 \mathrm{~cm}$ in combination with foliar spray of DAP (2\%)+Micro nutrient Spray (ZnSO @ 0.5\%+Boric acid @ 0.3\%)+NAA Spray (40 ppm) may be followed for obtaining high quantity and better quality seeds of sunnhemp. Effect of pinching and foliar nutrition on seed quality parameters revealed that seedling length was not significantly influenced by the pinching treatment while foliar applications had an effective role. Among different foliar applications, foliar spray of DAP (2\%)+Micro nutrient Spray ( $\mathrm{ZnSO}_{4} @ 0.5 \%+$ Boric Acid @ 0.3\%)+NAA Spray (40 ppm) best results. Vigour index of the seedlings indicated that pinching treatment did not make any significant differences while foliar application of different treatments had a significant role.
\end{abstract}

Keywords: Sunnhemp (Crotalaria juncea L.), growth, seed quality, seed yield

\section{Introduction}

Sunnhemp (Crotalaria juncea L.) belongs to family fabaceae is one of the oldest known fibres of the Indo-Pakistan subcontinent, produces a strong bast fibre from its bark which has greater tensile strength and is more durable under exposure than jute. Sunn fibre is stronger when wet, fairly resistant to mildew, moisture and micro-organisms in salt water, and is currently used in twine, rug yarn, cigarette and tissue papers, fishing nets, sacking, canvas and cordage. However, the potential of sunnhemp lies not just in its fibre but also in its use as a green manure and as forage for animals. It is one of the most outstanding green manure crops suited to almost all parts of the India (Ram and Singh, 2011). It is an erect, soft, woody annual, widely grown throughout the tropics and subtropics. Sunnhemp is also being looked at as a possible bio-fuel or short-lived perennial plant primarily used as green manure crop before transplanted rice. Sunnhemp is also a potential green manure crop which adds 150 to $165 \mathrm{~kg}$ of nitrogen $\mathrm{ha}^{-1}$ to the soil when grown for 60 days and then incorporated in test plots (Rotar and Joy, 1983).

The present day agriculture is primarily based on high cropping intensity with abundant use of chemical fertilizers that deteriorates the soil physical, chemical and biological properties. Green manuring, a part of organic farming builds soil fertility status by improving humas, organic carbon, nitrogen and microbial growth thereby increase the supply of nutrients available to plants. In this respect sunnhemp is a potential green manure crop which adds $8-21 \mathrm{t}$ of green matter and 42-95 kg N ha-1 (Mishra and Naik, 2004).

Despite having many valuable uses, acreage under this crop has drastically reduced primarily due to unavailability of good quality seeds (Chittapur and Kulkarni, 2003). Apical dominance can be removed by pinching the apical bud which promotes the development of lateral buds thereby resulting in increased branches plant ${ }^{-1}$ (Pathania et al., 2000; Aswath et al., 1994)) and ultimately increased the seed yield. Mandal et al. (2017) observed that pinching and foliar nutrition increases the seed yield of Dhaincha.

Since quality seed plays an important role in biomass as well as seed production of agricultural crops, the present investigation was carried out to study the effect of pinching and foliar nutrition on quality seed production of sunnhemp to improve the potentiality of the crop for more biomass as well as seed production. 


\section{Materials and Methods}

The field experiment was carried during kharif, 2015 and 2016 at Research Farm, Bidhan Chandra Krishi Viswavidyalaya, Mohanpur, West Bengal to study the effect of pinching and foliar nutrition on growth and yield of Sunnhemp (Crotalaria juncea L.). The research station is located at a height of 9.75 $\mathrm{m}$ above sea level $\left(23.5^{\circ} \mathrm{N}\right.$ latitude and $89^{\circ} \mathrm{E}$ longitude). Experiment was laid out in split-plot design with first factor at two levels viz. pinching of terminal bud $\left(P_{1}\right)$ and without pinching of terminal bud $\left(P_{0}\right)$ as main plot treatments. The second factor with five schedules of foliar spray viz. foliar spray with DAP $2 \%\left(\mathrm{~N}_{1}\right)$, foliar spray with MN Mixture ZnSo4 $0.5 \%+$ Boric acid $0.3 \%\left(\mathrm{~N}_{2}\right)$, foliar spray with NAA 40 PPM $\left(\mathrm{N}_{3}\right)$, foliar spray with DAP $2 \%+\mathrm{MN}$ Mixture+NAA $\left(\mathrm{N}_{4}\right)$ and Control $\left(\mathrm{N}_{5}\right)$ was laid out as sub plot treatments with four replications. The soil of the experimental site is clayey in texture with $\mathrm{pH}$ 6.9. Basal fertilizers @ $30 \mathrm{~kg} \mathrm{~N}$ and $50 \mathrm{~kg} \mathrm{P}_{2} \mathrm{O}_{5}$ ha $^{-1}$ were applied as the time of sowing. Crop was planted at a spacing of $30 \mathrm{~cm}$ row to row and $30 \mathrm{~cm}$ plant to plant. The sowing was done on 13.08.2015 and 31.07.16 and harvested on 08.12.2015 and 17.12.2016. Recommended agronomic packages and plant protection practices were adopted for raising the crop. Pinching of terminal buds was carried out when the main stem attains a height of $90 \mathrm{~cm}$ to encourage more branching and higher seed yield. Foliar sprays were given at flowering time. Data on various variables were analyzed by analysis of variance (Panse and Sukhatme, 1985) and OPSTAT software programme.

\section{Results and Discussion}

\subsection{Effect of pinching and foliar nutrition on growth parameters}

The data presented in Table 1 revealed that effect of pinching and foliar nutrition had a non significant effect on the character days to $50 \%$ flowering. This may be due to photoperiod sensitive nature of the crop as the crop flowers when the critical day length is below 11 hours (Lokesh et al., 2015). Pinching and foliar nutrition had also non significant effect on the character days to maturity of the crop. Maturity days were almost similar irrespective of foliar nutrition and pinching in both the years.

Pinching had a significant effect on average plant height where foliar nutrition had no such important role. In both the years, significantly higher plant height was recorded in without pinching treatment $(245.35 \mathrm{~cm}$, pooled) when compared to the pinching treatment $(223.55 \mathrm{~cm}$, pooled). The reduction in the height with pinching treatment was due to the effect of breaking the apical dominance by pinching and hence consequential increase in number of lateral branches which are in agreement with the findings of Aswath et al. (1994) in China aster, Khandelwal et al. (2003) in African marigold (Tagetes erecta L.) and Sharma et al. (2003) in pigeon pea. Though treatment $\mathrm{N}_{1}$ recorded highest plant height (240.55 $\mathrm{cm})$, there was no such significant effect of foliar nutrition

Table 1: Effect of pinching and foliar nutrition on growth parameters and yield and yield attributing characters of sunnhemp (Pooled data of 2015 and 2016)

\begin{tabular}{|c|c|c|c|c|c|c|c|c|c|c|}
\hline Treatments & $\begin{array}{c}\text { Days to } 50 \% \\
\text { flowering } \\
\text { (days) }\end{array}$ & $\begin{array}{l}\text { Days to } \\
\text { maturity } \\
\text { (days) }\end{array}$ & $\begin{array}{c}\text { Plant } \\
\text { height } \\
(\mathrm{cm})\end{array}$ & $\begin{array}{l}\text { Primary } \\
\text { branch } \\
\text { plant }^{-1}\end{array}$ & $\begin{array}{c}\text { No. of } \\
\text { pod } \\
\text { Plant }^{-1}\end{array}$ & $\begin{array}{c}\text { Pod } \\
\text { yield }(\mathrm{g}) \\
\text { plant }^{-1}\end{array}$ & $\begin{array}{l}\text { No of } \\
\text { seed } \\
\text { pod }^{-1}\end{array}$ & $\begin{array}{c}\text { Seed } \\
\text { yield }(\mathrm{g}) \\
\text { plant }^{-1}\end{array}$ & $\begin{array}{c}1000 \text { seed } \\
\text { weight } \\
\text { (g) }\end{array}$ & $\begin{array}{c}\text { Seed } \\
\text { yield } \\
(\mathrm{kg}) \mathrm{ha}^{-1}\end{array}$ \\
\hline \multicolumn{11}{|c|}{ Pinching effects } \\
\hline$P_{1}$ & 70.05 & 153.45 & 223.55 & 9.8 & 94.95 & 24.85 & 8.45 & 11.9 & 20.9 & 941.45 \\
\hline$P_{2}$ & 69.65 & 154.4 & 245.35 & 8.3 & 75.6 & 17.85 & 8.2 & 8.6 & 20.7 & 721.3 \\
\hline SEm \pm & 0.49 & 0.58 & 3.3 & 0.36 & 1.8 & 0.945 & 0.26 & 0.375 & 0.635 & 21.51 \\
\hline$C D(p=0.05)$ & NS & NS & 9.56 & 0.97 & 5.22 & 2.745 & NS & 1.095 & NS & 62.39 \\
\hline \multicolumn{11}{|c|}{ Foliar nutrition } \\
\hline $\mathrm{N}_{1}$ & 70.95 & 154.7 & 240.55 & 8.85 & 78.1 & 17.55 & 8.7 & 8.05 & 22.25 & 774.45 \\
\hline $\mathrm{N}_{2}$ & 70.5 & 153.8 & 229.75 & 8.6 & 86.8 & 21.85 & 8.75 & 9.95 & 20.55 & 768.55 \\
\hline $\mathrm{N}_{3}$ & 68.6 & 153.65 & 234.25 & 9.25 & 89.65 & 24.5 & 8 & 12.55 & 19.4 & 907.7 \\
\hline $\mathrm{N}_{4}$ & 69.55 & 153.7 & 239.15 & 9.4 & 95.05 & 26.75 & 8.15 & 13.35 & 21.8 & 1008.6 \\
\hline $\mathrm{N}_{0}$ & 69.6 & 153.85 & 228.65 & 9.15 & 76.85 & 16.05 & 8.1 & 7.35 & 20 & 697.7 \\
\hline SEm \pm & 0.775 & 0.92 & 5.215 & 0.53 & 2.845 & 1.495 & 0.41 & 0.6 & 1 & 33.1 \\
\hline $\mathrm{CD}(p=0.05)$ & NS & NS & NS & NS & 8.255 & 4.335 & NS & 1.73 & NS & 98.7 \\
\hline \multicolumn{11}{|c|}{ Interaction (VXN) } \\
\hline SEm \pm & 1.1 & 1.3 & 7.38 & 0.75 & 4.03 & 2.12 & 0.58 & 0.84 & 1.42 & 48.08 \\
\hline $\mathrm{CD}(p=0.05)$ & NS & NS & NS & NS & NS & 4.16 & NS & 2.45 & NS & 139.52 \\
\hline
\end{tabular}


with $\mathrm{N}_{1}$ treatment on height of sunhemp.

Primary branches plant ${ }^{-1}$ (Table 1 ) revealed that the character number of primary branches plant ${ }^{-1}$ was significantly influenced by pinching but foliar nutrition had no significant effect. In both the years, higher number of primary branches (9.8) was significantly higher with the pinching treatment than the without pinching plots (8.3). Removal of apical dominance by pinching the apical bud might have promoted the development of lateral buds thereby resulting in increased branches plant ${ }^{-1}$ (Pathania et al., 2000).

Among different foliar applications, treatment $\mathrm{N}_{4}$ recorded highest number of primary branches plant ${ }^{-1}$ (9.4) followed by $\mathrm{N}_{3}, \mathrm{~N}_{0}, \mathrm{~N}_{2}$ and $\mathrm{N}_{1}$ (Table 1).

\subsection{Effect of pinching and foliar nutrition on seed yield and yield contributing parameters}

Number of pod plant ${ }^{-1}$, pod yield (g plant ${ }^{-1}$ ), seed yield g plant ${ }^{-1}$ and seed yield $\left(\mathrm{kg} \mathrm{ha}^{-1}\right)$ showed significant effect on pinching and foliar nutrition (Table 1). This may be due to more number of seeds pod $^{-1}$ and test weight of seed. Significantly higher number of pods plant ${ }^{-1}$ (94.95) was recorded with pinching treatment when compared to the without pinching (75.6). Pinching seems to have released the apical dominance and hence consequential increase in number of lateral branches, healthy flowers which ultimately leads to higher number of pods per plant. Similar results were obtained in pigeon pea by Sharma et al. (2003). Among different foliar applications, treatment $\mathrm{N}_{4}$ recorded highest number of pods plant ${ }^{-1}(95.05)$ followed by $\mathrm{N}_{3}, \mathrm{~N}_{2}, \mathrm{~N}_{1}$ and $\mathrm{N}_{0}$.

Pod yield plant ${ }^{-1}$ was significantly influenced by both pinching and foliar nutrition. Similar observations were recorded in both the years. Significantly higher pod yield plant ${ }^{-1}$ was recorded with pinching treatment (24.85 g) against without pinching (17.85 g).

Foliar application had also significant effect on pod yield plant $^{-1}$. In both the year, treatment $\mathrm{N}_{4}$ i.e. foliar spray with DAP (2\%)+MN Spray ( $\mathrm{ZnSO}_{4} @ 0.5 \%+$ Boric acid @ 0.3\%)+NAA Spray $(40 \mathrm{ppm})$ recorded highest yield plant ${ }^{-1}(26.75 \mathrm{~g})$ which was followed by $\mathrm{N}_{3}, \mathrm{~N}_{2}, \mathrm{~N}_{1}$ and $\mathrm{N}_{0}$.

Foliar application of DAP, NAA combined with micronutrient registered highest pod yield. The causes for the increase in yield were the increased dry matter production and efficient assimilate translocation to the developing sink leading to increased pods and higher seed yield. These results are in conformity with the findings of Revanthy et al. (1997).

Number of seed per pod was not significantly influenced by pinching and foliar nutrition. Number of seed pod $^{-1}$ is a genetic character so it was not influenced by the pinching as well as different combination of foliar nutrition. Similar observation was also recorded by Tripathi et al. (2013) in sunnhemp.

The influence of pinching and foliar applications on seed yield plant $^{-1}(\mathrm{~g})$ indicated that pinching, foliar nutrition as well as the treatment combination had significant role on seed yield plant $^{-1}(\mathrm{~g})$. Pinching had a significant influence on the character seed yield plant ${ }^{-1}(\mathrm{~g})$. Significantly higher yield was recorded with pinching. Pinching treatment recorded $11.9 \mathrm{~g}$ of seed yield plant ${ }^{-1}$ when non pinching treatment gave seed yield of 8.6 g per plant (pooled data).

Among different foliar applications, highest seed yield plant ${ }^{-1}$ was recorded with foliar spray with DAP (2\%)+MN Spray ( $\mathrm{ZnSO}_{4} @ 0.5 \%+$ Boric acid @ 0.3\%)+NAA spray (40ppm) i.e. in $\mathrm{N}_{4}$ treatment $\left(13.35 \mathrm{~g}\right.$ ) followed by $\mathrm{N}_{3}, \mathrm{~N}_{2}, \mathrm{~N}_{1}$. The performance of $\mathrm{N}_{4}$ and $\mathrm{N}_{3}$ was statistically at par. Interaction effect of seed yield plant ${ }^{-1}$ and seed yield $\left(\mathrm{kg} \mathrm{ha}^{-1}\right)$ as influenced by pinching and foliar found significant. Similar results was observed by Mandal et al, 2017 in Dhaincha.

The Influence of pinching and foliar applications on seed yield $\left(\mathrm{kg} \mathrm{ha}^{-1}\right)$ presented in Table 1 , revealed that both pinching and foliar nutrition had a significant role on seed yield. Over the years, average seed yield ha-1 was significantly higher when pinching was followed. Pinching treatment recorded seed yield of $941.45 \mathrm{~kg} \mathrm{ha}^{-1}$ as compare to the without pinching treatment $\left(721.3 \mathrm{~kg} \mathrm{ha}^{-1}\right)$. The maximum yield observed under the effect of pinching might be attributed to growth characteristics which resulted inconsiderable improvement in yield attributing characters like pods plant ${ }^{-1}$ and seed yield plant $^{-1}$ and finally reflected into yield. Further, more branches plant ${ }^{-1}$ under pinching treatment might have had multiplicative effect on seed yield.

Among different foliar applications, treatment $\mathrm{N}_{4}$ i.e. foliar spray with DAP (2\%)+MN Spray ( $\mathrm{ZnSO}_{4} @ 0.5 \%+$ Boric acid @ 0.3\%)+NAA spray (40 ppm) recorded highest seed yield (1008.6 kg ha ${ }^{-1}$ ) followed by $N_{3}, N_{1}, N_{2}$ and $N_{0}$. Here influence of $\mathrm{N}_{4}$ and $\mathrm{N}_{3}$ was statistically similar. The seed yield of $\mathrm{N}_{4}$ and $\mathrm{N}_{3}$ was significantly higher than the other three treatments. Foliar applications of nutrients at the critical stages of the crop were effectively absorbed by the plant and translocated to the developing pods, producing more number of pods, more filling and higher yield. Significant improvement in seed yield with spray of DAP, NAA and micronutrients like zinc and boron indicate that these nutrients play an important role in several enzymatic processes and are necessary for growth and development of the crop. They further contribute to increased branches, pods and seed yield. This could be attributed to the fact that boron plays an important role in cell divisions, cell differentiation, development, calcium utilization, translocation of photosynthates and growth regulators from source to sink, and help in maintaining higher leaf area, leaf area index and higher number of pods plant ${ }^{-1}$ (Kalyani et al., 1993). It also helps in preventing flower drop, pod drop and there by maintaining higher number of pods plant ${ }^{-1}$. Observed yield advantage in response to the application of NAA which delays maturity may be attributed to the prolonged canopy life of the plant which enables the plant to produce adequate photo assimilates for an extended period. Revanthy et al. (1997) reported that foliar spray of DAP, NAA combined with micronutrients registered higher grain yield. The causes for 
the increase in yield were the increased dry matter production and efficient assimilate translocation to the developing sink leading to increased pods and higher seed yield.

Among the interaction effects, $\mathrm{P}_{1}$ and $\mathrm{N}_{4}$ i.e. pinching in combination with foliar spray of DAP (2\%)+Micronutrient mixture ( $\mathrm{ZnSO}_{4} @ 0.5 \%+$ +Boric acid @ 0.3\%)+NAA (40 ppm) recorded significantly highest seed yield when compared to the control i.e. treatment combination $\mathrm{P}_{0}-\mathrm{N}_{0}$.

Test weight (1000 seed weight) of the produce obtained from sunnhemp crop as influenced by pinching and foliar nutrition presented in Table 1. It was revealed that pinching had no significant role on 1000 seed weight of the crop. Tripathi et al. (2013) worked on sunnhemp, reported that different topping practices in sunhemp did not exert any significant influence on number of seeds pod $^{-1}$ and test weight. Among different foliar applications, though $\mathrm{N}_{1}$ recorded the highest result (22.25 g) but there was no significant effect of foliar nutrition on 1000 seed weight of sunnhemp.

\subsection{Effect of pinching and foliar nutrition on seed quality parameters}

Germination percentage of the seeds produced from the sunnhemp experimental plot was influenced neither by the pinching nor by the foliar applications (Table 2). Though higher germination percentage was recorded with $\mathrm{P}_{1}$ i.e. pinching treatment $(78.0 \%)$, it did not differ significantly from without pinching treatment (77.4\%). Non significant differences were also recorded among the different sub treatments. Though

\begin{tabular}{|c|c|c|c|}
\hline Treatments & $\begin{array}{c}\text { Germination } \\
\text { percentage }\end{array}$ & $\begin{array}{l}\text { Seedling } \\
\text { length }\end{array}$ & $\begin{array}{l}\text { Vigour } \\
\text { index }\end{array}$ \\
\hline \multicolumn{4}{|c|}{ Pinching effects } \\
\hline$P_{1}$ & 78.0 & 9.4 & 732.1 \\
\hline$P_{2}$ & 77.4 & 9.1 & 704.0 \\
\hline SEm \pm & 1.54 & 0.32 & 24.54 \\
\hline $\operatorname{CD}(p=0.05)$ & NS & NS & NS \\
\hline \multicolumn{4}{|c|}{ Foliar nutrition } \\
\hline $\mathrm{N}_{1}$ & 76.1 & 8.2 & 624.4 \\
\hline $\mathrm{N}_{2}$ & 79.1 & 8.8 & 691.8 \\
\hline $\mathrm{N}_{3}$ & 78.3 & 10.0 & 779.8 \\
\hline $\mathrm{N}_{4}$ & 78.8 & 10.7 & 843.3 \\
\hline $\mathrm{N}_{0}$ & 76.1 & 8.6 & 651.1 \\
\hline SEm \pm & 2.43 & 0.51 & 38.81 \\
\hline $\mathrm{CD}(p=0.05)$ & NS & 1.48 & 112.64 \\
\hline \multicolumn{4}{|c|}{ Interaction (VXN) } \\
\hline SEm \pm & 3.43 & 0.72 & 54.88 \\
\hline $\operatorname{CD}(p=0.05)$ & NS & NS & NS \\
\hline
\end{tabular}

highest germination percentage was recorded on $\mathrm{N}_{2}$ followed by $\mathrm{N}_{4}, \mathrm{~N}_{3}, \mathrm{~N}_{1}$ and $\mathrm{N}_{0}$.

Seedling length (Table 2 ) revealed that the character average seedling length was not significantly influenced by the pinching treatment while foliar applications had an effective role.

Among different foliar applications, significantly highest seedling length was recorded after $\mathrm{N}_{4}(10.7 \mathrm{~cm})$ followed by $\mathrm{N}_{3}, \mathrm{~N}_{2}, \mathrm{~N}_{0}$ and $\mathrm{N}_{1}$. However statistically similar performance was recorded by $N_{4}$ and $N_{3}$ with respect to average seedling length of sunnhemp.

Vigour index (Table 2) of the seedlings harvested from the sunnhemp plot indicated that pinching treatment did not make any significant differences while sub treatments had a significant role.

Though numerically pinching treatment recorded higher vigour index (732.1) when compared to the without pinching treatment (704.0). Significant differences were found among different sub treatments. Highest vigour index was recorded in $\mathrm{N}_{4}$ (843.3) followed by $\mathrm{N}_{3}, \mathrm{~N}_{2}, \mathrm{~N}_{0}$ and $\mathrm{N}_{1}$, Treatments $\mathrm{N}_{4}$ and $\mathrm{N}_{3}$ had significantly similar effect on vigour index of sunnhemp seedlings.

\section{Conclusion}

Pinching of sunnhemp at a height of $90 \mathrm{~cm}$ in combination with foliar spray of DAP (2\%)+Micro nutrient Spray $\left(\mathrm{ZnSO}_{4} @\right.$ 0.5\%+Boric Acid @ 0.3\%)+NAA Spray (40 ppm) at flowering stage may be recommended for obtaining higher seed yield. Seedling length and vigour index of sunnhemp was effectively influenced by the foliar applications. The present study revealed differential interaction effect of pinching and foliar applications on the character seed yield $\left(\mathrm{kg} \mathrm{ha}^{-1}\right)$.

\section{Acknowledgement}

The authors are grateful to ICAR-Indian Institute of Seed Science Mau, Uttar Pradesh, India for providing the seed material under AICRP-NSP (Crops) and financial assistance to conduct the experiment.

\section{References}

Aswath, S., Gowda, J.V.N., Murthy, G.M.A., 1994. Effect of growth retardants on growth, flowering and nutrient contents in China aster, (Callistephus chinesis L. Ness). Journal of Ornamental Horticulture 2(12), 9-13.

Chittapur, B.M., Kulkarni, S.S., 2003. Effect of sowing dates on the performance of sunnhemp. Journal of Maharashtra Agricultural Universities 28(3), 331.

Kalyani, R., Ratna Devi, V., Satyanarayana, N.V., Rao, S., Madhava Rao, K.V., 1993. Effect of foliar application of boron on crop growth and yield of pigeon pea. Indian Journal of Plant Physiology 36(4), 223-226.

Khandelwal, S.K., Jain, N.K., Singh, P., 2003. Effect of growth retardants and pinching on growth and yield of African 
marigold (Tagetes erecta L.). Journal of Ornamental Horticulture 6(3), 271-273.

Lokesh, D., Megha, D., Jain, P., 2015. Role of green manuring in organic farming. Plant Archives 15(1), 23-26.

Mandal, S., Dutta, A., Bhattacharyya, P.K., 2017 Effect of Pinching and foliar nutrition on growth and yield of Dhaincha (Sesbania rostrata). International Journal of Current Research 9(10), 59676-59681.

Mishra, B.B., Nayak, K.C., 2004. Organic farming for sustainable Agriculture. Orissa Review, 42-45.

Panse, V.G., Sukhatme, P.V., 1985. Statistical method for Agricultural Workers. Indian Council of Agricultural Research, New Delhi (4 ${ }^{\text {th }}$ Edn.).

Pathania, N.S., Sehgal, O.P., Gupta, Y.C., 2000. Pinching for flower regulation in sim carnation. Journal of Ornamental Horticulture 3, 114-117.

Ram, H., Singh, G., 2011. Growth and seed yield of sunnhemp genotypes as influenced by different sowing methods and seed rates. World Journal of Agricultural Sciences 7(1), 109-112.

Rotar, P. P., Joy, R. J., 1983. 'Tropic Sun' sunn hemp, Crotalaria juncea L. Research Extension Series 036. College of Tropical Agriculture and Human Resources, University of Hawaii. P. 1.

Sharma, A., Poddar, M.P., Pujari, B.T., Dharmaraj, P.S., Sharma, A., 2003. Studies on response of pigeon pea to canopy modification and plant geometry. Karnataka Journal of Agricultural Sciences 16, 1-3. 